\title{
Statyba
}

\section{AVERAGE STRESS-STRAIN RELATIONS FOR CONCRETE FROM EXPERIMENTAL MOMENT-STRAIN DIAGRAMS OF BEAMS AND SLABS}

\section{G. Kaklauskas PhD}

To cite this article: G. Kaklauskas PhD (1998) AVERAGE STRESS-STRAIN RELATIONS FOR CONCRETE FROM EXPERIMENTAL MOMENT-STRAIN DIAGRAMS OF BEAMS AND SLABS, Statyba, 4:2, 92-100, DOI: 10.1080/13921525.1998.10531387

To link to this article: https://doi.org/10.1080/13921525.1998.10531387

Published online: 26 Jul 2012.

Submit your article to this journal $\llbracket$

LIII Article views: 267 


\section{AVERAGE STRESS-STRAIN RELATIONS FOR CONCRETE FROM EXPERIMENTAL MOMENT-STRAIN DIAGRAMS OF BEAMS AND SLABS}

\section{G. Kaklauskas}

\section{Introduction}

Recently a new method [1-6] has been developed for determining the average concrete stress-strain relationships from experimental moment-strain (curvature) diagrams for reinforced concrete beams in bending.

The method is based on smeared crack approach. Average stress-strain relations for concrete in tension (including the descending branch) and in compression are computed from equilibrium equations using experimental moment-average strain and/or momentcurvature curves. Computation of stress-strain relations is performed incrementally for the extreme surface fibres, and is based on a novel idea of using the previously computed portions of the stress-strain relations at each load increment to compute the current increments of the stress-strain relations. The proposed method has been tested numerically $[1,2]$.

Experimental data often contain a considerable amount of measurement scatter which may result in oscillatory and irregular results. Based on the method proposed, two practical techniques being less sensitive to measurement scatter have been developed [2]. By the first technique, an average stress-strain relation for concrete in tension is determined from one experimental moment-average strain (or curvature) diagram when the stress-strain relation for concrete in compression is assumed to be known. By the second technique, in an iterative way using two experimental moment-average strain (curvature) diagrams average stress-strain relations for concrete in tension as well as in compression are defined. In this case, just the shape of the parabolic stress-strain relationship for concrete in compression is assumed and its parameters such as modulus of elasticity and prism (cylinder) strength of concrete are determined by computation.

In this paper, the proposed techniques are applied to experimental data reported by Clark and Speirs [7]. Fourteen beams and nine slabs having different section depth, reinforcement ratio and bar diameter and spacing have been investigated.

\section{Experimental specimens}

The method proposed in [1-6] is applied to experimental data reported by Clark and Speirs [7]. Their experimental program was devoted to investigation of tension stiffening effects. Fourteen beams with various depths, reinforcement ratios and diameter and nine slabs with various steel areas and bar arrangements were tested (Table 1). The beams and slabs were tested in an inverted position under a four-point loading system which gave a constant moment zone of $1.2 \mathrm{~m}$ and two shear spans of $1.0 \mathrm{~m}$ each.

Table 1. Nominal geometrical data of specimens

\begin{tabular}{|c|c|c|c|c|}
\hline Specimen & $\begin{array}{c}\text { Width } \\
(\mathrm{mm})\end{array}$ & $\begin{array}{c}\text { Depth } \\
(\mathrm{mm})\end{array}$ & $\begin{array}{c}\text { Reinfor- } \\
\text { cement } \\
\text { ratio } \\
(\%)\end{array}$ & $\begin{array}{c}\text { Reinfor- } \\
\text { cement } \\
\text { diameter } \\
(\mathrm{mm})\end{array}$ \\
\hline Beams & & & & \\
1 and $1 \mathrm{R}$ & 200 & 400 & 1.95 & 25 \\
2 and $2 \mathrm{R}$ & 200 & 400 & 1.27 & 20 \\
3 and 3R & 200 & 400 & 0.79 & 16 \\
4 and $4 \mathrm{R}$ & 200 & 400 & 0.45 & 12 \\
5 and $5 \mathrm{R}$ & 200 & 200 & 1.78 & 16 \\
6 and 6R & 200 & 300 & 1.10 & 16 \\
7 and 7R & 200 & 500 & 0.63 & 16 \\
\hline Slabs & & & & \\
1,2 and 3 & 900 & 200 & 1.24 & 20 \\
4,5 and 6 & 900 & 200 & 0.79 & 16 \\
7,8 and 9 & 900 & 200 & 0.44 & 12 \\
\hline
\end{tabular}

Beams. The beams were nominally $3.5 \mathrm{~m}$ long, $200 \mathrm{~mm}$ wide and were reinforced with three bars. Two series of beams were tested: in the first series (beam numbers 1 through 4 ), the overall depth was held constant and steel area and diameter varied. In the second series (numbers 3,5,6, and 7), the steel area was kept constant and the overall depth was 
varied. Stirrups in the shear spans and top reinforcement were provided in accordance with requirements of the British Code of Practice [8]. In Table 1, the letter ' $R$ ' after the specimen number indicates that a second nominally identical beam was also cast and tested.

Slabs. All slabs were nominally $3.5 \mathrm{~m}$ long, 900 $\mathrm{mm}$ wide and $200 \mathrm{~mm}$ deep and were reinforced with six bars. Reinforcing bars in slabs 1,4 , and 7 were distributed evenly across the width of the specimen, in slabs 2, 5, and 8 bars were arranged in bundles of two and in slabs 3,6, and 9 bars were arranged in bundles of three. The bar spacings were thus $2 / 3,1.5$ and 2.25 times the slab depth respectively. Top steel and stirrups in the shear spans were also provided.

Reinforcement. Deformed bars were used for the main reinforcement. Complete stress-strain diagrams for that reinforcement which had a modulus of elasticity $E_{s}$ of $2.06 \times 10^{5} \mathrm{MPa}$ are presented in [7]. The steel became non-linear at a strain of 1400 to 1600 microstrain, corresponding to a stress of about three quarters of its ultimate strength.

Concete. Data on the concrete mix, cube strength, indirect tensile strength, modulus of elasticity and age at test are given in [7]. Although it was intended that the concrete strength at test be similar for all specimens, the cube strength varied from 23.0 to 39.6 $\mathrm{MPa}$. All slabs were tested at an age of 28 days while the age at test varied from 21 to 41 days for the beams.

Unfortunately, no information was provided about curing conditions. As it will be shown later, curing conditions affect shrinkage which may lead to significant initial tensile concrete stresses, particularly for members with high reinforcement ratios.

Measurements of strains and deflections. Concrete surface strains were measured on a $200 \mathrm{~mm}$ gauge length, using a Demec gauge. For the beam tests, strains were measured throughout the length of the zone of pure bending along four continuous gauge lines located at different depths on one side of the beam. The two extreme gauge lines were located at the level of the centroids of the bottom and top reinforcement and the other two gauge lines were equally spaced in between. For the slab tests, strains were also continuously measured on the top and bottom surfaces along lines parallel to the span and situated at $1 / 4,1 / 2$, and $3 / 4$ of the width of the slab.
For strain and curvature assessment, measured strains were averaged along each gauge line. Average curvature over the constant moment zone was also defined from the deflection gauge readings. The tests were terminated before the steel strain reached 2000 microstrains.

Experimental results in Ref [7] are presented in terms of moment-curvature, $(M-\kappa)$, and momentsteel strain, $\left(M-\varepsilon_{s}\right)$, diagrams for each of the specimens.

\section{Analysis of experimental specimens}

In the present research, concrete material $\sigma-\varepsilon$ diagrams are computed by the two techniques presented in [2]. Both techniques employ the following stress-strain relationship for compressive concrete:

$$
\begin{gathered}
\sigma_{c}=f_{c}^{\prime}\left[2 \frac{\varepsilon_{c}}{\varepsilon_{0}}-\left(\frac{\varepsilon_{c}}{\varepsilon_{0}}\right)^{2}\right] \\
\varepsilon_{0}=2 f_{c}^{\prime} / E_{c}
\end{gathered}
$$

where $\sigma_{c}$ and $\varepsilon_{c}$ are the stress and strain respectively of the compressive concrete; and $f_{c}^{\prime}$ and $\varepsilon_{0}$ are the maximum compressive stress and the corresponding strain for standard prism (or cylinder) test.

By the first technique, an average $\sigma_{t}-\varepsilon_{t}$ relation is determined from one experimental moment-average strain (or curvature) diagram when the behaviour of the compressive concrete is modelled by experimental cylinder $\sigma_{c}-\varepsilon_{c}$ curve or by $\mathrm{Eq} 1$ using experimental values of $E_{c}$ and $f_{c}^{\prime}$ (Table 2). In this research two $\sigma_{t}-\varepsilon_{t}$ relations were determined for most of the specimens using both experimental moment-curvature $(M-\kappa)$, and moment-steel strain, $\left(M-\varepsilon_{s}\right)$, diagrams.

By the second technique, in an iterative way using two experimental moment-average strain (curvature) diagrams average stress-strain relations for concrete in tension as well as in compression are defined. In this case, just the shape of the parabolic stress-strain relationship for concrete in compression (Eq 1) is assumed and its parameters such as modulus of elasticity and prism (cylinder) strength of concrete are determined by computation. In this research, one iteration involved computation of the $\sigma_{t}-\varepsilon_{t}$ curve from the $M-\varepsilon_{s}$ diagram and subsequent determination of the $\sigma_{c}-\varepsilon_{c}$ curve from the $M-\kappa$ diagram. 
Table 2. Experimental and computed material parameters for compressive concrete

\begin{tabular}{|c|c|c|c|c|c|c|c|}
\hline Specimen & $\begin{array}{c}E_{c, \exp } \\
\left(\times 10^{3}\right) \\
{[\mathrm{MPa}]}\end{array}$ & $\begin{array}{c}E_{c, a s} \\
\left(\times 10^{3}\right) \\
{[\mathrm{MPa}]}\end{array}$ & $E_{c, a s} / E_{c, \exp }$ & $\begin{array}{l}f_{c, \exp }^{\prime} \\
{[\mathrm{MPa}]}\end{array}$ & $\begin{array}{c}f_{c, a s}^{\prime} \\
{[\mathrm{MPa}]}\end{array}$ & as & $\varepsilon_{0}$ \\
\hline \multicolumn{8}{|l|}{ Beams } \\
\hline 1 & 26.5 & 27.5 & 1.04 & 27.0 & 27.5 & 1.02 & 0.0020 \\
\hline $1 \mathrm{R}$ & 29.9 & - & - & 27.8 & - & - & 0.0019 \\
\hline 2 & 28.0 & 29.0 & 1.04 & 26.6 & 29.0 & 1.09 & 0.0019 \\
\hline $2 \mathrm{R}$ & 30.5 & 36.0 & 1.18 & 31.7 & 36.0 & 1.14 & 0.0021 \\
\hline 3 & 30.3 & 36.5 & 1.20 & 30.5 & 36.5 & 1.20 & 0.0020 \\
\hline $3 \mathrm{R}$ & 35.1 & 35.1 & 1.00 & 29.2 & 35.1 & 1.20 & 0.0017 \\
\hline 4 & 25.0 & 35.0 & 1.40 & 23.1 & 35.0 & 1.52 & 0.0018 \\
\hline $4 \mathrm{R}$ & 28.9 & 34.0 & 1.18 & 25.0 & 340 & 1.36 & 0.0017 \\
\hline 5 & 21.0 & 20.0 & 0.95 & 23.4 & 20.0 & 0.85 & 0.0022 \\
\hline $5 \mathrm{R}$ & 26.6 & 20.5 & 0.77 & 28.2 & 20.5 & 0.73 & 0.0021 \\
\hline 6 & 25.2 & 21.0 & 0.83 & 21.0 & 21.0 & 1.00 & 0.0017 \\
\hline $6 \mathrm{R}$ & 28.6 & 28.6 & 1.00 & 27.3 & 28.6 & 1.05 & 0.0019 \\
\hline 7 & 25.0 & 32.0 & 1.28 & 18.4 & 32.0 & 1.74 & 0.0015 \\
\hline $7 \mathrm{R}$ & 27.5 & 35.0 & 1.27 & 23.4 & 35.0 & 1.50 & 0.0017 \\
\hline \multicolumn{8}{|l|}{ Slabs } \\
\hline 1 & 27.8 & 27.8 & 1.00 & 28.3 & 27.8 & 0.98 & 0.0022 \\
\hline 2 & 27.1 & 29.5 & 1.09 & 28.7 & 29.5 & 1.03 & 0.0021 \\
\hline 4 & 28.9 & 27.0 & 0.93 & 26.4 & 27.0 & 1.02 & 0.0018 \\
\hline 5 & 27.1 & 29.5 & 1.09 & 21.4 & 29.5 & 1.38 & 0.0016 \\
\hline 7 & 25.9 & 25.9 & 1.00 & 22.5 & 25.9 & 1.15 & 0.0017 \\
\hline 8 & 22.7 & 22.7 & 1.00 & 26.9 & 22.7 & 0.84 & 0.0024 \\
\hline
\end{tabular}

Average concrete material $\sigma_{t}-\varepsilon_{t}$ diagrams can be computed either from experimental data or from defined material properties. For all specimens except beam $1 \mathrm{R}$ and slabs 3,6, and 9, analyses were performed for both sets of material properties. For the sake of brevity, these two analyses are categorized cases $\mathrm{A}$ and $\mathrm{B}$ as explained below:

Case A: Concrete compressive properties are based on experimental data presented in [7]. For the given modulus of elasticity $E_{c, \exp }$ and a cylinder compressive strength $f_{c, \text { exp }}^{\prime}$ taken as $80 \%$ of the cube strength, $\varepsilon_{0}$ was assumed from Eq 1(b).

Case $B$ : The modulus of elasticity $E_{c, a s}$ is determined from computation. The parameter $\varepsilon_{0}$ relating $E_{c, a s}$ and $f_{c, a s}^{\prime}$ is assumed to be 0.002 . Then in accordance with Eq (1) $f_{c, a s}^{\prime}$ is taken as 1000 times smaller than $E_{c, a s}$. The resultant experimental parameters are listed in Table 2.

Analysis by the proposed method is illustrated for beam 7 of the test series which had the second smallest reinforcement ratio and could therefore be expected to show significant tension stiffening effects. The measured $M-\varepsilon_{s}$ and $M-\kappa$ diagrams are reproduced from [7] and presented in Fig 1 with the experimental data points shown by circles. From these diagrams, four main stages of structural behaviour for reinforced concrete members subjected to bending moment can be observed. During the first stage, strains increase linearly with increasing moment and behaviour can be considered linearly elastic. The second stage referred to as the transitional stage starts soon after tensile crack initiation. Since concrete can not carry the same tensile stresses before and after cracking, stress redistribution takes place with cracking and is accompanied by a sudden stress increase in the tensile reinforcement. The third stage for most of specimens is characterized by an almost linear increase in strain and curvature with increasing moments, but now at a rate very different from that for the first stage. The diagrams for some specimens had a well defined 'saw' shape. This effect can be explained not only by creep effects or inaccuracy of 
measurements, but also by the discrete nature of cracking. The fourth stage starts with the commencement of reinforcement yielding which leads to significant increases in both compressed concrete and steel tension strains. This stage was not included into the present investigation since the experiments were terminated prior to, or at the onset of, the yielding of the reinforcement.

$a$

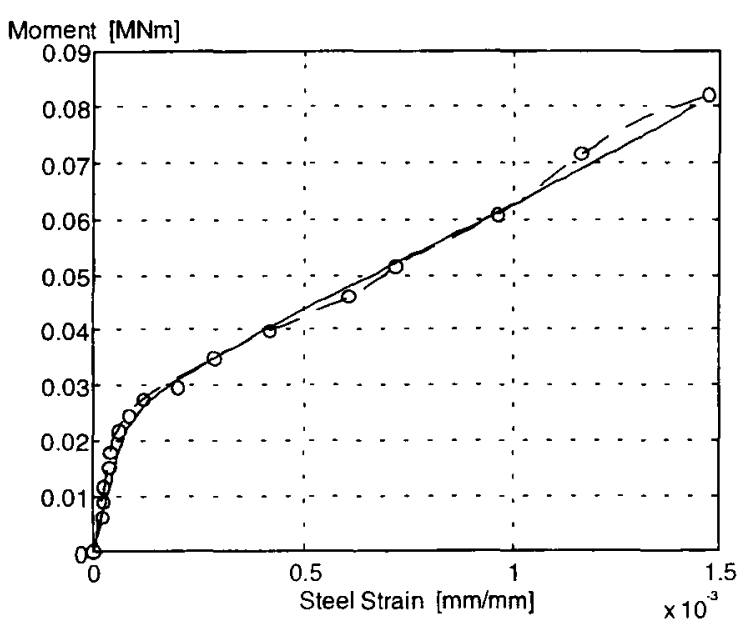

$b$

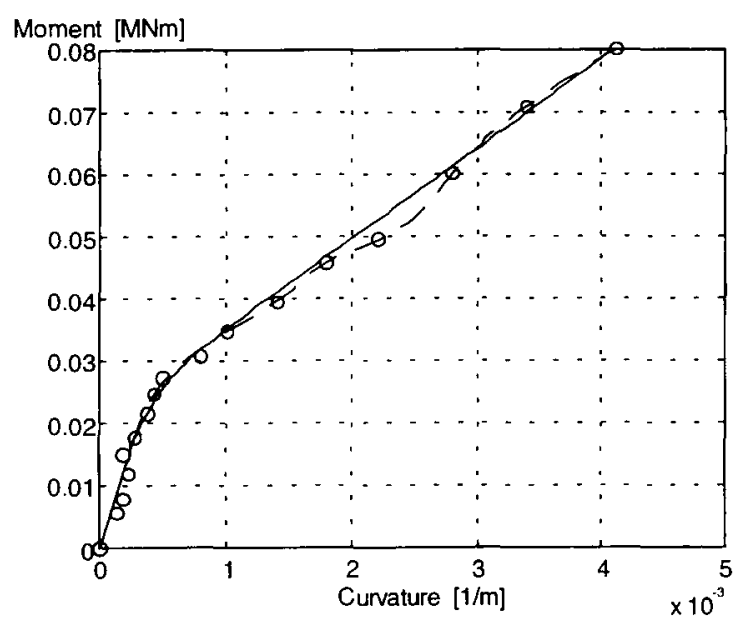

Fig 1. Experimental $M-\varepsilon_{s}$ and $M-\kappa$ relationships for beam 7: $a-M-\varepsilon_{s}$ relationships; $b-M-\kappa$ relationship; oooo - experimental data;

- . - smoothed curve;

_ averaged and smoothed curves

For specimens with high reinforcement ratios, the transitional stage was short and smooth. Possibly the result was due to the ability of the reinforcement to restrict sudden crack development. On the other hand, members with small reinforcement ratios usually had long transitional stages for which the strain rates were often significantly higher than those in the third stage. Because of the small amounts of reinforcement, cracking caused significant increases in stresses and strains in the reinforcement which was not as capable of restricting further concrete cracking as was the case for beams with high reinforcement ratios.

As it is noted in [2], the measured $M-\varepsilon_{s}$ and $M-\kappa$ diagrams were smoothed for purposes of analysis. Numerically smoothed diagrams for beam 7 are shown by dashed lines in Fig 1. Further to obtain reasonable results, several experimental points recorded during the early stages of loading had to be omitted. Due to the saw-shape distribution of experimental points, the smoothed diagrams have slightly wavy form. For these diagrams, the computed $\sigma_{t}-\varepsilon_{t}$ curves (case A) are as shown by dashed lines in Fig 2. The wavy-shape of the curves is due to the similar form (although to much lesser extent), of the wavy shape of the $M-\varepsilon_{s}$ and $M-\kappa$ diagrams. A common explanation is that the increase in stiffness (decreasc in strain rates) in the moment-strain (curvature) diagrams leads to an increase in stress rates in the $\sigma-\varepsilon$ curves. Since the computational method is based on a smeared crack approach, which deals with average reinforcement and concrete strains, it cannot reflect the phenomenon of discrete cracking which is responsible for the wavy shape of the strain diagrams. In order to obtain smoothed shapes for the material $\sigma-\varepsilon$ diagrams, the experimental $M-\kappa$ and $M-\varepsilon_{s}$ curves had to be averaged [1,2]. In the present study, the curves were averaged by MATLAB [9] in such a manner as to possibly avoid increasing the stiffness (or decreasing the strain and curvature rates). Averaging can be performed by the least square method. However, for practical purposes the averaged curve can be simply constructed using several characteristic experimental points. For most of the cases analyzed, 5-8 experimental points were sufficient to obtain a numerically averaged curve which adequately represented all experimental points.

The initial experimental points corresponding to the elastic part of moment-strain (curvature) diagrams were often non-reliable. Since the response in the elastic part is associated with small strains, inaccuracies arise due to experimental techniques, graphical presentation (the figures in [7] were drawn manually) and due to data scanning from the publication. Therefore, curvatures and strains from the elastic interval were based on the results of elastic 
computations and not on results from measurements. Usually 2-3 points are sufficient for numerical presentation of the elastic part by MATLAB [9]. The extreme point in the elastic part of the $M-\kappa$ and $M-\varepsilon$ diagrams defines the maximum stress in the computed $\sigma_{t}-\varepsilon_{t}$ diagram which in turn corresponds to the tensile strength of the concrete. The computations showed that the location of that extreme point did not significantly affect the remaining part of the $\sigma_{t}-\varepsilon_{t}$ curve.

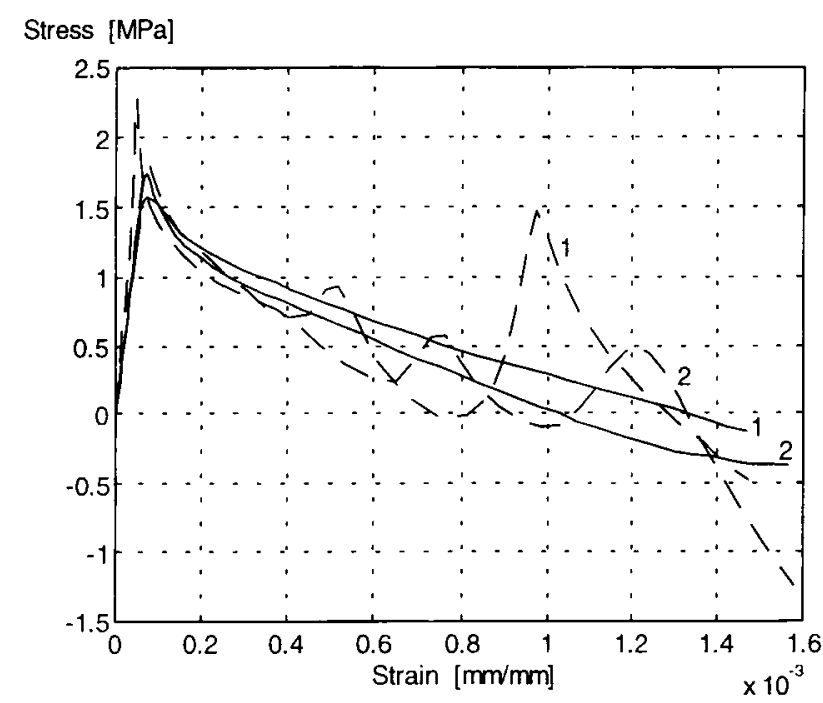

Fig 2. Tensile concrete $\sigma-\varepsilon$ curves (case A) for beam 7 : - - - computed from smoothed $M-\varepsilon_{s}$ and $M-\kappa$ relationships;

- computed from averaged and smoothed $M-\varepsilon_{s}$ and $M-\kappa$ relationship: 1 - obtained from $M-\kappa ; 2$ - obtained from $M-\varepsilon_{s}$

It is expected that future research, based on accurately measured experimental data, can result in a more rigorous method for averaging moment-strain (curvature) curves and provide further insight into the properties of the $\sigma-\varepsilon$ diagrams.

Averaged $M-\varepsilon_{s}$ and $M-\kappa$ diagrams for beam 7 are presented in Fig 1 by solid lines. The computed $\sigma_{t}-\varepsilon_{t}$ curves for these diagrams using the measured compressive concrete properties of $E_{c, \text { exp }}=2.5 \times 10^{4}$ $\mathrm{MPa}, f_{c, \text { exp }}^{\prime}=18.4 \mathrm{MPa}$, and $\varepsilon_{0}=0.0015$ (Table 2) are shown in Fig 2 by solid lines. Computed and assumed $\sigma_{c}-\varepsilon_{c}$ diagrams (case B) for the final iteration are shown in Fig 3. The values assumed for the modulus of elasticity $E_{c, a s}=3.2 \times 10^{4} \mathrm{MPa}$ and the compressive strength $f_{c, a s}^{\prime}=32.0 \mathrm{MPa}$ signifiantly exceed the experimental ones of $E_{c, \exp }$ and $f_{c, \exp }^{\prime}$ from Table 2.

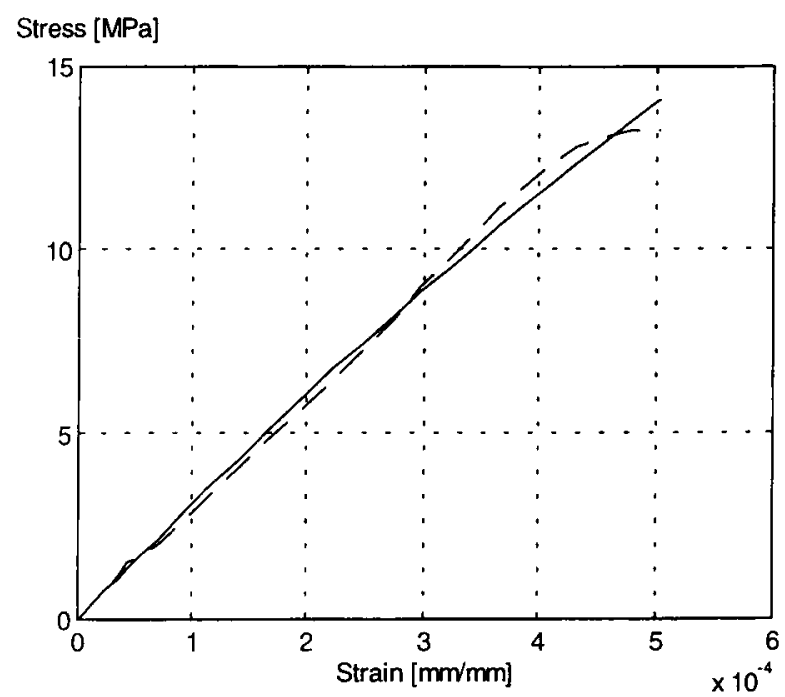

Fig 3. Computed and assumed compressive concrete $\sigma-\varepsilon$ curve for beam 7 :

- . - computed in final iteration;

- assumed

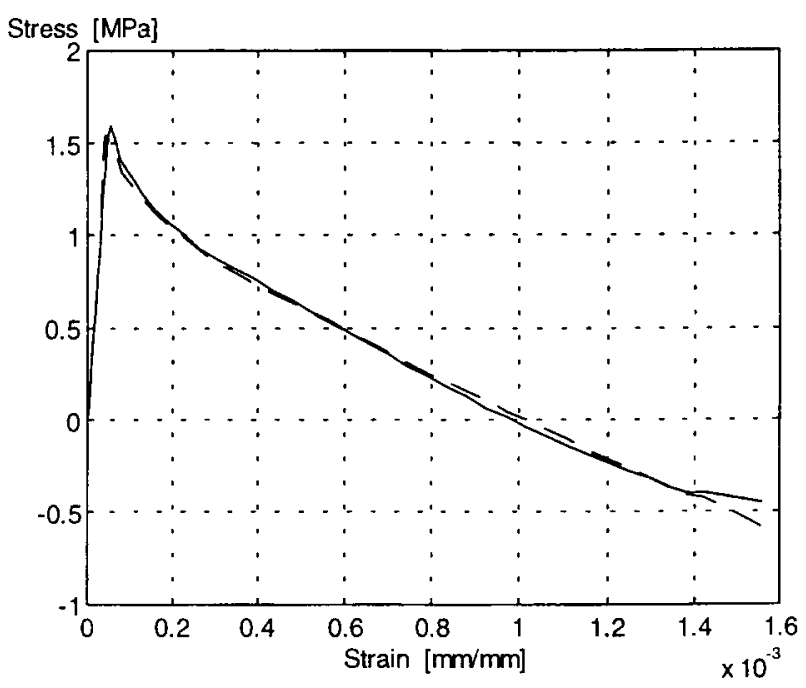

Fig 4. Tensile concrete $\sigma-\varepsilon$ curves (case B) for beam 7:

- computed from $M-\varepsilon_{s}$ relationship

.. computed from $M-\kappa$ relationship

However, use of these higher assumed values had little effect on the two computed $\sigma_{t}-\varepsilon_{t}$ curves (case B) which show excellent agreement. This is a typical example where the two $\sigma_{t}-\varepsilon_{t}$ curves computed from the $M-\kappa$ and $M-\varepsilon_{s}$ diagrams (Fig 4) approach closer to one another in case $B$ than the two curves computed for case A (Fig 2). 
In addition to the measured $M-\kappa$ diagram, another moment-curvature diagram $M-\kappa_{s}$ is obtained when the $\sigma_{t}-\varepsilon_{t}$ curve is computed from the $M-\varepsilon_{s}$ diagram. If the resulting $M-\kappa_{s}$ relation coincides with the $M-\kappa$ relation, a unique solution for $\sigma_{c}-\varepsilon_{c}$ and $\sigma_{t}-\varepsilon_{t}$ is achieved since they were obtained from two different moment-strain (curvature) diagrams which fully define the strain state. Usually the $M-\kappa_{s}$ relation is closer to the $M-\kappa$ relation for case B than for case A. A comparison of these curves for beam 7 is presented in Fig 5. Very good agreement between the measured and computed relations has been achieved for case B, but some discrepancy can be noted for case $\mathrm{A}$.

The computed variation in the relative depth of the compressive zone (ratio of the compressive depth to the overall depth) as a function of moment is given in Fig 6. Fig 7 shows the variation with increasing moment in the ratio of the tensile force carried by the tensile concrete to the total tension force. The solid line indicates the horizontal force relation and the dashed line the moment action. Since these curves did not coincide for any of the specimens investigated, the assumption made by some investigators that the resultant of the tensile concrete coincides with the centroid of reinforcement is not accurate.

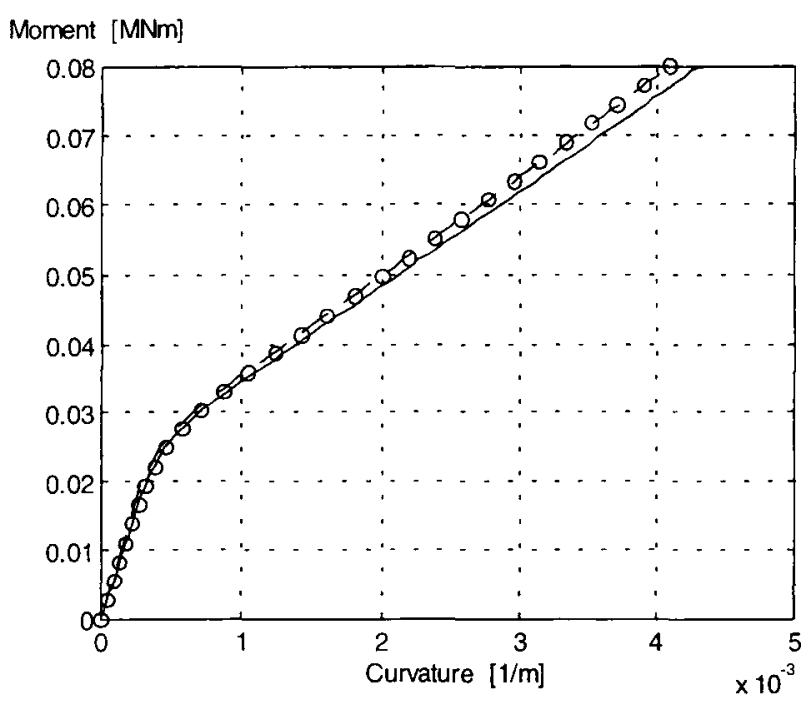

Fig 5. Moment-curvature relationships for beam 7: oooo - averaged and smoothed experimental - . . - computed when $\sigma_{t}-\varepsilon_{t}$ curve was obtained from $M-\varepsilon_{s}$ relationship (case A)

- the same (case B)

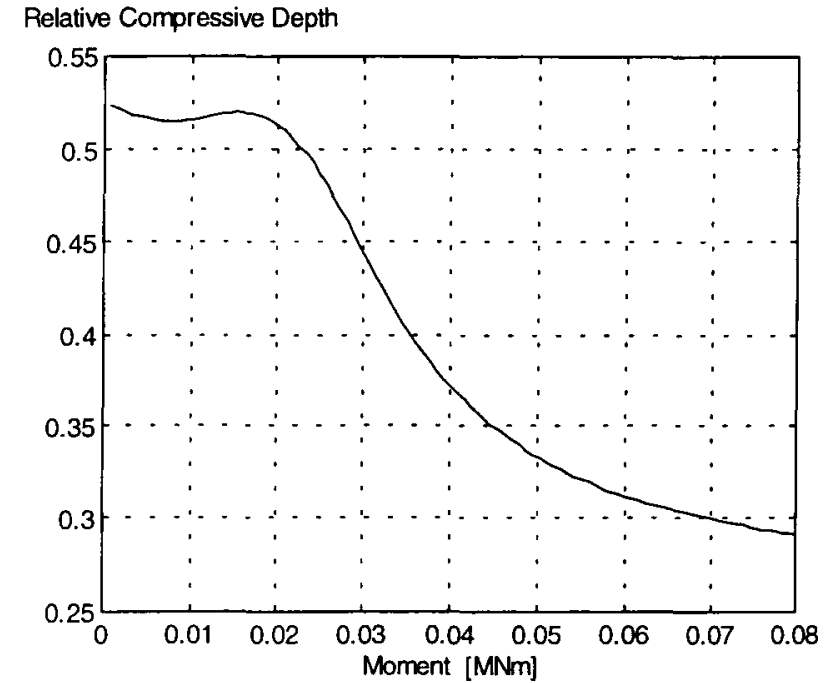

Fig 6. Relative depth of the compressive zone with increasing moment

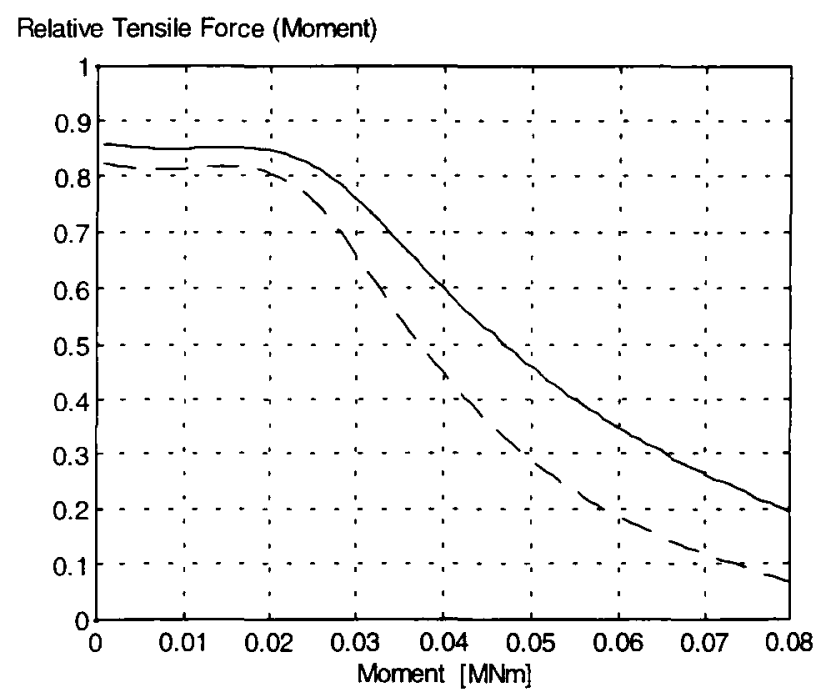

Fig 7. Relative influence of tensile concrete in overall tension action with increasing moment

- horizontal force action

-. - - moment action

Investigations similar to that shown for beam 7 were performed for all the beams and slabs reported in [7]. Good agreement for the two $\sigma_{t}-\varepsilon_{t}$ curves computed from the experimental $M-\kappa$ and $M-\varepsilon$

relations were obtained for all beams and slabs except beam $1 \mathrm{R}$. For this beam, a reasonable $\sigma_{t}-\varepsilon_{t}$ curve was obtained from the $M-\kappa$ diagram, but an obviously incorrect $\sigma_{t}-\varepsilon_{t}$ curve was computed from the $M-\varepsilon_{s}$ diagram. Some reservations can be expressed for beams 5 and $5 \mathrm{R}$ since their $M-\mathrm{K}$ and $M-\varepsilon_{s}$ diagrams in [7] are produced in a small scale, resulting in some discrepancies in the moment values 
for the corresponding experimental points. However, beams $1(R)$ and $5(R)$ had the highest reinforcement ratio (Table 1) and, therefore, the influence of the tensile concrete on the overall tensile force action is the least significant for those specimens. Errors made in determination of $\sigma_{t}-\varepsilon_{t}$ diagram for members having reinforcement ratio over $1.5 \%$ do not have any significant effect on the results of the curvature or deflection calculations.

High accuracy of the test data for beams is indicated not only by the good agreement between the $\sigma_{t}-\varepsilon_{t}$ curves computed from the $M-\kappa$ and $M-\varepsilon_{s}$ relations, but also by the similarity of the $\sigma_{t}-\varepsilon_{t}$ curves obtained for twin specimens. However, the latter conclusion cannot also be drawn for slabs which showed more scatter in the computed results. Most probably this is caused by the different width of the beams and slabs what influenced the choice of locations for the strain gauges. It is known that average tensile concrete strains measured at the level of the reinforcement (as was the case for the beams) are more accurate and consistent than tensile strains measured on extreme tensile surface (as was the case for the slabs), because the latter will be more affected by the locations of the discrete cracks. In addition, measurements of strains and deflections in slabs are also affected by stress variations across the width due to the spacing of reinforcing bars. Finally, the number of strain gauges per unit volume was much greater for the beams than for the slabs and that can be expected to result in more consistent readings.

Compressive concrete $\sigma_{c}-\varepsilon_{c}$ relations for case $B$ were determined for all the specimens except beam $1 \mathrm{R}$ and slabs 3,6 , and 9. Computed $\sigma_{c}-\varepsilon_{c}$ relation parameters $E_{c, a s}$ and $f_{c, u s}^{\prime}$ are compared to the experimentally determined parameters $E_{c, \exp }$ and $f_{c, \exp }^{\prime}$ in Table 2. Discrepancies between the computed and experimental data can be explained by the following: 1) inaccuracies in measured and assumed moment-strain (curvature) diagrams; 2) scatter in the material test results; 3) the material properties in the beams and slabs being different from those in the control specimens; 4) differences between the behaviour of concrete in concentric compression (as in a cylinder) and that in eccentric compression (as in a beam). In beams a strain gradient is present and a redistribution of stresses can take place. Highly strained concrete fibres close to a compression surface are aided by less strained material located closer to the neutral axis. However, this condition is more applicable to advanced stress and strain states where tension stiffening effects are absent or not significant; and 5) the shape assumed for the $\sigma_{c}-\varepsilon_{c}$ diagram of Eq (1) which may not be accurate.

The greatest discrepancy between the experimental and computed $E_{c}$ and $f_{c}^{\prime}$ values occurs for beams $4(\mathrm{R})$ and $7(\mathrm{R})$ having the smallest reinforcement ratios. As was shown for case of beam 7, variations in the $E_{c}$ and $f_{c}^{\prime}$ values for members with low reinforcement ratios have little effect on the computed $\sigma_{t}-\varepsilon_{t}$ relations. Such members have relatively small neutral axis depths and a change in compressive strength does not significantly effect the moment arm between the resultants of the tensile and compressive forces. That is the reason why the $\sigma_{c}-\varepsilon_{c}$ computation for such members is not sensitive to variation in $E_{c}$ and $f_{c}^{\prime}$ values. Naturally, high accuracy requirement for experimental momentstrain (curvature) diagrams is essential for members with low reinforcement ratio in determining $\sigma_{c}-\varepsilon_{c}$ curves. By contrast, for members with high reinforcement ratios, inaccuracies in the momentstrain (curvature) diagrams affect the tensile concrete diagram significantly, but have little effect on the compressive concrete diagram. As it can be seen from Table 2, much better agreement between the computed and experimental $E_{c}$ and $f_{c}^{\prime}$ has been achieved for specimens with high reinforcement ratios than for those with low ratios (Table 1). As it noted previously, errors made for such members in computation of $\sigma_{t}-\varepsilon_{t}$ diagrams has little effect on curvature and deflection calculations.

The $\sigma_{t}-\varepsilon_{t}$ relations obtained from $M-\kappa$ diagrams using experimental material data (case A) for beams of the first and second series are shown in Figs 8 and 9 respectively. The main conclusion can be drawn that the $\sigma_{t}-\varepsilon_{t}$ relations mostly depend on reinforcement ratio and diameter of reinforcement bars. The extension of the descending branch of the curves reflecting the tension stiffening effect was considerably more pronounced for beams with smaller reinforcement ratio and diameter what particularly evident for the beams of the first series (Fig 8). A detailed analysis of the $\sigma_{t}-\varepsilon_{t}$ relations discussing influence of different parameters on these relations will be presented in future publications [10]. 


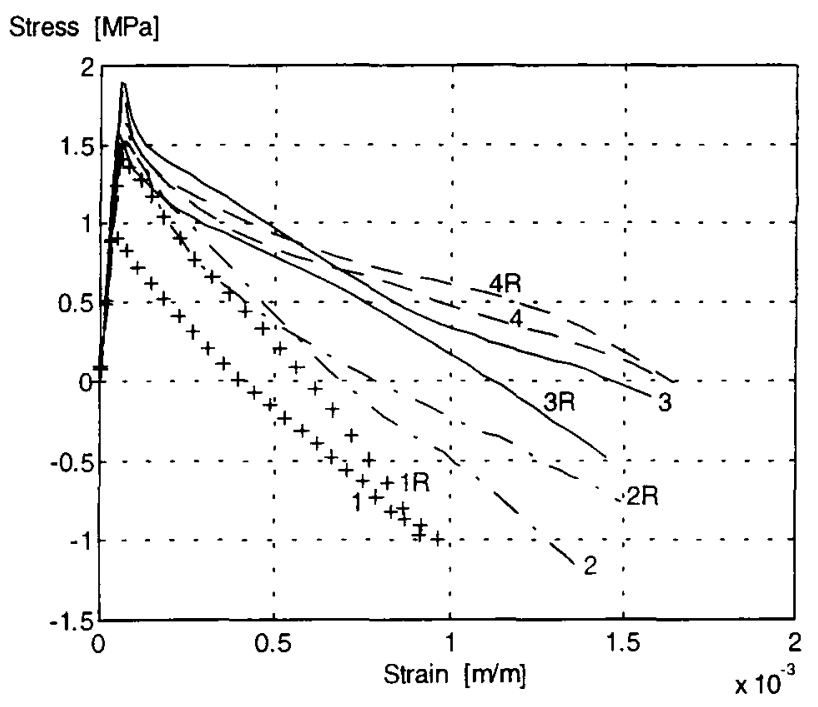

Fig 8. Tensile concrete stress-strain relationships for the beams of the first series having constant section height but varying reinforcement area and diameter

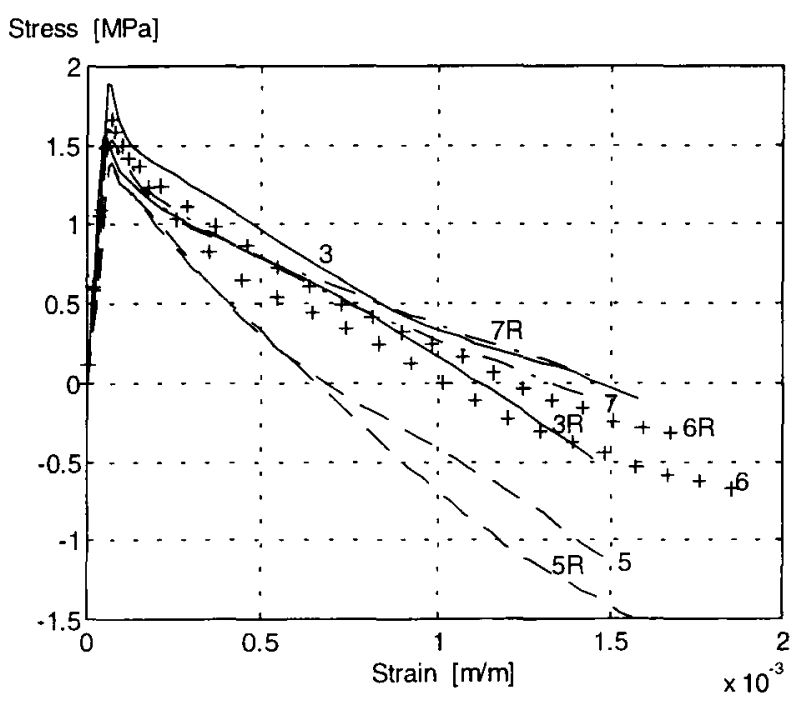

Fig 9. Tensile concrete stress-strain curves for the beams of the second series having constant reinforcement area and diameter but varying section height

As it was noted, accuracy of experimental data for the slabs was not sufficient to determine the influence of different parameters on tension stiffening effect. Therefore, the $\sigma_{t}-\varepsilon_{t}$ relations for slabs are not presented herein.

\section{Conclusions}

Recently proposed method [1-6] for determining average stress-strain relationships for concrete from experimental data of flexural members has been successfully applied to a number experiments of beams and slabs reported in literature [7]. By the method in an iterative way using two experimental moment-average strain (curvature) diagrams average stress-strain relations for concrete in tension as well as in compression are defined. Average stress-strain curves for concrete in tension were computed for specimens with various depths, reinforcement ratios and reinforcement bar diameters. Analysis has shown that the $\sigma_{t}-\varepsilon_{t}$ relations mostly depend on reinforcement ratio and diameter of reinforcement bars. The extension of the descending branch of the curves reflecting the tension stiffening effect was considerably more pronounced for beams with smaller reinforcement ratio and diameter.

Parameters of compressive concrete such as modulus of elasticity and cylinder strength were determined by computation. The computed values of modulus of elasticity matched well the experimental data and the values of cylinder strength were in reasonable agreement.

\section{Acknowledgments}

Part of this work was carried out in the Department of Civil Engineering of the University of Illinois, Urbana-Champaign, USA. Professors J.Ghaboussi and N.Hawkins are gratefully thanked for their critical support and advice throughout the research. The financial support provided by the University of Illinois and US Information Agency under Fulbright grant is gratefully acknowledged.

\section{References}

1. G. Kaklauskas. A Method for Determination of StressStrain Relations for Concrete from Experimental Data of RC Bending Members // Statyba, No 2(10). Vilnius: Technika, 1997, p. 60-68.

2. G. Kaklauskas. Practical Techniques for Determining Average Stress-Strain Relationships for Concrete from Experimental Data of RC Bending Members // Statyba, No 1(13). Vilnius: Technika, 1998, p. 20-28.

3. G. Kaklauskas. A Method for Investigation of Tension Stiffening Effect of Flexural RC Members // Proceedings, Conf. Building and Architecture, Kaunas, Lithuania, April 9-11, 1997, p. 157-164.

4. G. Kaklauskas, J. Ghaboussi and N.M. Hawkins. Determination of Stress-Strain-Curves for Concrete from RC Beam Tests // Proceedings, Fifth Int. Conf. Modern Building Materials and Techniques, Vilnius, Lithuania, May 21-24, 1997. V.: Technika, 1997, p. 138-145.

5. G. Kaklauskas. A Technique for Investigation of Tension Stiffening Effect of Flexural RC Members // Proceedings, 10th Nordic Seminar on Computational Mechanics, Tallin, Estonia, October 24-25, 1997, p. 228231. 
6. G. Kaklauskas, J. Ghaboussi, and X. Wu. Neural Network Modelling of Tension Stiffening Effect for R/C Flexural Members // Proceedings, EURO-C 1998- Computational Modelling of Concrete Structures, Badgastein, Austria, March 31 - April 3, 1998 ( to be published).

7. A. Clark and D.M. Speirs. Tension Stiffening in Reinforced Concrete Beams and Slabs under Short-Term Load // Technical Report No 42.521, Cement and Concrete Association, London, 1978. 20 p.

8. British Standards Institution. The Structural Use of Concrete. Part 1: Design, materials and workmanship. London, 1972. 154 p. CP 110: Part 1.

9. The Student Edition of Matlab: Version 4. The MathWorks Inc. Prentice Hall, Englewood Cliffs, 1995.

10. G. Kaklauskas. Average Stress-Strain Relationships for Concrete in Tension from Flexural Tests // Statyba. Vilnius: Technika (to be published in 1998).

İteikta 19980306

BETONO VIDUTINIU ITEMPIU-DEFORMACIJU DIAGRAMU NUSTATYMAS IŠ EKSPERIMENTINIŲ SLJU BEI PLOKŠČIŲ MOMENTŲ-DEFORMACLJU KREIVIU

\section{G. Kaklauskas}

S a n t r a u k a

Neseniai autorius pasiūlè naują apskačiavimo metodą, pagal kurị [1-6] iš lenkiamų gelžbetoniniu sijų arba plokščių eksperimentiniu duomenu gali būti nustatytos betono vidutinių ittempių-deformaciju diagramos. Turint eksperimentines momentų-kreiviu ir momentų-deformacijų diagramas, gaunama išsami tempiamo betono vidutiniu ịtempių-deformaciju diagrama, įskaitant ir jos krintančiają dalị. Taip pat, net neturint duomeny apie betono savybes, pakankamai tiksliai galima nustatyti ir gniuždomo betono diagramą. Ankstesniuose šio žurnalo numeriuose $[1,2]$ buvo pateiktas teorinis metodo pagrindimas, skaitinis patikrinimas ir praktinés apskaičiavimo metodikos. Šiame straipsnyje pateikti šio metodo taikymo eksperimentinių duomeny rezultatai. Buvo atlikta 14 siju ir 9 plokščių, kruopščiai išbandytų anglų tyrinetojų Clarko ir Speirso [7], analizè. Sijos ir plokštès turejo skirtingą skerspjūvio aukštị, armavimo koeficientą ir armatūros strypų skersmenị (1 lentelè). Jos buvo apkrautos dviem koncentruotomis jegomis, tarp kuriu buvo $1,2 \mathrm{~m}$ ilgio gryno lenkimo ruožas. Sijos buvo suskirstytos ị dvi grupes (serijas): pirmosios serijos (Nr. 1-4) sijos turejo skirtingą aukštị, skirtingą armatūros strypu skersmenị ir skerspjūvio plotą. Antrojoje serijoje (Nr. 3, 5, 6 ir 7) armatūros strypu skerspjūvio plotas ir skersmuo buvo vienodas, tačiau kito sijų skerspjūvio aukštis. Raide $R$ bandinio numeryje (1 lentele) rodo, jog buvo išbandyta identiška sija. Literatüros šaltinyje [7] pateiktos visų eksperimentinių bandiniu momentu-kreiviu ir momentų-vidutiniu armatūros deformacijų diagramos.

Išsamus tyrimas, naudojant pasiūlytaji skaičiavimo metodą, atliktas su 7 sija (1 lentelè). Buvo parodytos sijos darbo stadijos ir detaliai aprašyti visi žingsniai, nustatant tempiamo (ir gniuždomo) betono vidutinių ittempiųdeformacijų diagramas. Parodyta, kad dèl diskretaus gelžbetoninių elementy pleišejjimo pobūdžio, eksperimentiniu momentų-kreivių (deformacijų) diagramos dažnai panašios i pjüklo dantelius ( 1 pav.). Turint tokias deformacijų diagramas, tempiamo betono įtempių-deformacijų kreivès gaunamos panašios, t.y. banguotos (2 pav.). Tam imamos "išlygintos" momentų-kreivių (deformacijų) kreivès (1 pav.), iš kurių nustatomos analogiškos ittempiųdeformaciju kreives.

Tempiamo betono vidutiniu įtempių-deformaciju diagramos pirmosios ir antrosios seriju sijoms pateiktos atitinkamai 8 ir 9 pav. Gautosios diagramos labai skiriasi ir svarbiausiais itakojančiais faktoriais laikomi armavimo koeficientas bei tempiamos armatūros strypu skersmuo. Mažejant šiems dydžiams, tempiamo betono vidutinių ịtempių-deformacijų kreivių krintanti dalis pastebimai ilgèja ir rodo padidejusią supleišejusio tempiamo betono ịtaka bendram skerspjūvio ir viso elemento standumui.

Gintaris KAKLAUSKAS. PhD, Senior Researcher and Associate Professor. Dept of Reinforced Concrete Structures, Vilnius Gediminas Technical University, Sauletekio al. 11, 2040 Vilnius, Lithuania.

A graduate of Vilnius Civil Engineering Institute (presently Vilnius Gediminas Technical University, VGTU), 1982 (civil engineer). PhD degree, 1990. Research visits: Aalborg University (Denmark), 1991, University of Glamorgan (UK), 1994/1995, University of Illinois, UrbanaChampaign (USA), 1996. Author and co-author of 2 monographs, 1 invention and a number of papers. Research interests: development of average stress-strain relationships for concrete in tension and numerical simulation of reinforced concrete flexural structures. 